\title{
Are Journalists to be Punished for Doing their Job?
}

\author{
TRINE BAUMBACH*
}

\section{Introduction}

'Are journalists to be punished for doing their job?' This is a question that is frequently asked by journalists when journalistic working methods or conduct are on the agenda. As elegant as the question is from an oratorical point of view, it is impossible to answer with a firm yes or no from a legal point of view.

Firstly, it is necessary to point out that journalists generally are free to do all the things people outside their occupation are allowed to. They are not restricted by any special article in the criminal law on journalistic conduct. Journalists are thus free to try to get an interview with a person - known or unknown to the public, in addition to be free to quote whoever he or she wants. Journalists are free to research a topic using all available, lawful means - searching the internet, looking up information in the library, calling on experts, carrying out on-the-spot investigations etc. In addition, journalists are free to go anywhere open to the public, or to private places, if invited. On the whole, journalists are free to do all the things people are free to do in a free society.

Secondly, it is to be noted that journalists cannot, in principle, be released from their duty to obey the ordinary criminal law on the basis that freedom of expression and their vital role as public watchdog endow them with special immunity from criminal liability. This applies to all the criminal law provisions that do not by their nature constitute

Associate Professor, PhD, Centre for Public Regulation and Administration, Faculty of Law, University of Copenhagen. 
a limitation of freedom of expression - for instance research acts committed as part of the journalist's data collection. ${ }^{1}$

Despite this ascertainment of the facts, the reality is not always as simple. This is due to the fact that some topics are of such important public interest that they must be reported by the press. In these extraordinary situations the criminal law can appear to be an unnecessary obstacle to journalists in their research, in the sense, as will be argued below, that the balancing of the conflicting interests must result in favour of the public's right to information. However, this is also due to the fact that some journalists disregard the law if they get what they themselves think is a good idea for an article or a broadcast. Some journalists may not perhaps disregard the law when doing their job, but however constantly attempt to challenge the legal boundaries set up by criminal law - and from time to time prove successful.

In the following, I will analyse different types of journalistic working methods and conduct which give rise to criminal proceedings against journalists and, in that connection, emphasise why it is important to make legal distinctions between each of them. To begin with, I will briefly review the rules on journalists' freedom of expression and provide some comments on the duties and responsibilities imposed on them. The analyses will have their legal basis in the European Convention on Human Rights and the European Court of Human Rights (the Court's) case law. Eventually, I will make some concluding remarks.

\section{Freedom of Expression and Freedom of the Press - Article 10 of the European Convention on Human Rights}

As stated several times by the Court, freedom of expression constitutes one of the essential foundations of a democratic society and one of the basic conditions for its progress and for the self-fulfilment of each individual. ${ }^{2}$ However, as set forth in Article 10 (2), freedom of expression is not absolute and is subject to exceptions. These exceptions must, however, be construed strictly, and in every single case the need for a restriction must be established convincingly. In this connection, it is crucial to bear in mind that freedom of expression is not only applicable to information and ideas that are favourably received or regarded as either inoffensive or as a matter of indifference. Freedom of expression also applies to information and ideas that offend, shock or disturb. The Court has pointed out

E.g. unlawful purchase of weapons to show in an article or broadcast how easy it is. See further below.

2 See Handyside v. the United Kingdom, appl. no 5493/72, 7.12.1976, para. 49 and Couderc and Hachette Filipacchi Associes v. France, appl. no. 40454/07, 10.11.2015 (Grand Chamber), para. 88. 
that this is a consequence of the demands of pluralism, tolerance and broadmindedness, without which there would be no democratic society. ${ }^{3}$ In a media law context the Court has emphasised that journalistic freedom of expression also covers possible recourse to a degree of exaggeration or even provocation. ${ }^{4}$

A part of freedom of expression is the right to information, or as stated in Article 10 , 'to receive ... information and ideas. ${ }^{5}$ Freedom of the press is deduced from this right, as it is the task of the press to impart information and ideas on all matters of public interest. Not only does the press have this task, the public has a definite right to receive the information and ideas. Without access to information from the press, the public does not have a genuine possibility to keep up with the developments in society. Neither do they have the possibility to debate matters of public interest and thereby sway developments, perhaps even turn the tide and change the direction of society.

Moreover, without information from the press, the public will be unable to monitor whether the authorities or powerful private enterprises are acting within the framework of a democratic society governed by the rule of law. In other words, the press has a special status in a democratic society, on behalf of the public, to play the role of, sometimes said, the 'fourth power' or as the so-called 'public watchdog.'

As seen from the expression, the press is not just a watchdog, it is the public watchdog. The special status which the press and journalists enjoy in a democratic society in relation to freedom of expression is not enjoyed in their personal capacity, so to speak, but in their function as public watchdog.?

As mentioned, the right to freedom of expression under Article 10 is not absolute. Thus, according to Article 10 (2), freedom of expression can be subject to interference if the type of interference is prescribed by law and is necessary in a democratic society, in the interests of national security, territorial integrity or public safety, for the prevention of disorder or crime, for the protection of health or morals, for the protection

3 See e.g. Axel Springer AG v. Germany, appl. no. 39954/08, 7.2.2012 (Grand Chamber), para. 78. See also Lillo-Stenberg and Seether v. Norway, appl. no. 13258/09, 16.1.2014, para. 28 and Gibbons, Media and Freedom of Expression: State Regulation is Necessary for Freedom of Expression, in Media and Human Rights, ed. Clemens Nathan, (Clemens Nathan Research Centre 2009) pp. 38 ff.

$4 \quad$ See among others Delfi AS v. Estonia, appl. no. 64569/09, 16.6.2016 (Grand Chamber), para. 132.

$5 \quad$ Including the right to internet access, see Ahmet Yildirim v. Turkey, appl. no. 3111/10, 18.12.2012.

6 See Axel Springer AG v. Germany (n 3), para. 79. See also the Council of Europe's Parliamentary Assembly Resolution 2035 (2015) final version, on Protection of the safety of journalists and of media freedom in Europe, Barendt, Freedom of Speech (Oxford University Press 2005) pp. 417 ff. and Jacobs, White \& Ovey, The European Convention on Human Rights (Oxford University Press 2014) pp. $444 \mathrm{ff}$.

$7 \quad$ See e.g. Kjølbro, Den Europaiske Menneskerettighedskonvention - for praktikere (Jurist- og Økonomforbundets Forlag 2010) pp. 760 f. 
of the reputation or rights of others, for preventing the disclosure of information received in confidence, or for maintaining the authority and impartiality of the judiciary.

It appears that, in its own review of a case in hand, the Court finds it to be of great importance whether the national courts in substance have conducted a proper examination of the case in accordance with Article 10 and the criteria identified and developed by the Court in previous case law. ${ }^{8}$ However, if a case concerns a matter of great public interest, the Court has emphasised that there is only little scope under Article 10 (2) to restrict freedom of expression. ${ }^{9}$

\section{Duties and Responsibilities - Ethics of Journalism}

The bedrock principles behind freedom of the press imply that the introductory remarks in Article 10 (2) on 'duties and responsibilities' have a special significance in press cases. ${ }^{10}$ By reason of the duties and responsibilities inherent in the exercise of the freedom of expression, the safeguard given to journalists by Article 10, in relation to the reporting on issues of general interest, is subject to the proviso that they act in good faith in order to provide accurate and reliable information in accordance with the ethics of journalism, ${ }^{11}$ 'even with respect to matters of serious public concern'. ${ }^{12}$ In this context it is of paramount importance that journalists view their sources critically and try to verify the relevant information. ${ }^{13}$

According to the Court, it follows from the ethics of journalism as well that before publishing an interview, a journalist must both verify that a statement made in one context is reproduced in such a way that, as regards content, it is adequate and that a direct quotation is accurate. However, it is not permissible to require by means of criminal

$8 \quad$ See e.g. Mikkelsen and Christensen v. Denmark, appl. no. 22918/08, 24.5.2011 (dec.), Hlynsdottir v. Iceland (No. 2),appl. no. 54125/10, 21.10.2014, para. 54 and 65, Lillo-Stenberg and Soether v. Norway (n 3), para. 44, Niskasaari and Otavamedia OY v. Finland, appl. no. 32297/10, 23.6.2015, para. 58 ff. and Prompt v. France, app. no. 30936/12, 3.12.2015, para. 45 f. See also Jakobsen \& Schaumburg-Müller, Medieretten (the Media Law) (Jurist- og Økonomforbundets Forlag 2013) pp. $110 \mathrm{ff}$. and Baumbach, Strafferet og menneskeret (Criminal Law and Human Rights) (Karnov Group Denmark A/S 2014) pp. $344 \mathrm{f}$.

$9 \quad$ See e.g. Mondragon v. Spain, appl. no. 2034/07, 15.3.2011, para 50.

10 See also Harris, O’Boyle \& Warbrick, Law of the European Convention on Human Rights (Oxford University Press 2014) pp. 687 ff.

11 See among many others Bladet Tromsø and Stensaas v. Norway, appl. no. 21980/93, 20.5.1999 (Grand Chamber), para. 65 and Cojocaru v. Romania, appl. no. 32104/06, 10.2.2015, para. 23.

12 See e.g. Axel Springer AG v. Germany (n 3), para. 82.

13 See Haldimann and Others v. Switzerland, appl. no. 21830/09, 24.2.2015, para. $46-47$ and Ziembinski v. Poland, appl. no. 46712/06, 24.7.2012, para. 53 f. 
penalties that journalists are to obtain permission to publish an interview (conducted without subterfuge or deceit). Such a requirement would have a 'chilling effect' and a devastating impact on the public's right to receive information. This would apply even if the concrete sentence is lenient. ${ }^{14}$ Journalists and the media are also not under an obligation to inform individuals who appear in an article or a television broadcast, in advance, that material or information concerning them is to be published. ${ }^{15}$ Nor is the use of a hidden camera necessarily a breach of the ethics of journalism if used in accordance with the public interest and the subsequent broadcast of the recording is not distorted. ${ }^{16}$

In modern times, it is worth noticing that internet portal operators engaged in media publication are also required to act in accordance with the ethics of journalism. ${ }^{17}$ In other words, it is not the medium, but the subject matter that determines the rules.

\section{The Individual Journalistic Working Methods and Conduct}

Journalistic working methods or conduct, leading to a journalistic story that gives rise to criminal proceedings against a journalist, can be categorised in various ways. With reference to the Court's case law, the following categories are suggested. First, I will deal with the issue of the journalistic reporting privilege, before looking into the two kinds of journalistic self-staged stories that give special rise to legal considerations. Then I will discuss crimes committed in connection with data collection, before finally making some remarks about journalists' own defamatory statements. This categorization is not unequivocal, since some journalistic methods and conduct may belong to more than one category. ${ }^{18}$ However, in the light of the Court's case law, this approach seems to be the most suitable.

14 See in more detail Wizerkaniuk v. Poland, appl. no. 18990/05, 5.7.2011, para. $65 \mathrm{ff}$.

15 See Mosley v. the United Kingdom, appl. no. 48009/08, 10.5.2011, para. $106 \mathrm{ff}$. On ethics of journalism regarding the duty of the media to publish retort, see Kapersynski v. Poland, appl. no. 43206/07, 3.4.2012, para. 67.

16 See Haldimann and Others v. Switzerland (n 13), para. $56 \mathrm{ff}$.

17 See Delfi AS v. Estonia (n 4), para. 113. However, the particular nature of the Internet implies that the duties and responsibilities that are to be conferred on an Internet news portal for the purposes of Article 10 may differ to some extent from those of a traditional publisher as regards third-party content. See also Albrecht \& Andreassen, Etik for journalister på nettet (Ethics for journalists on the internet), (Forlaget Ajour Denmark 2014).

18 See also Barendt, An overlap of defamation and privacy?, 7(1) Journal of Media Law (2015) pp. 85 ff. Criminal provisions are not defined uniformly in each country and some acts may be criminalised in one country and 'only' met with civil sanctions in another country. In some countries the legal basis is reversed. This is e.g. the case in Norway where the criminal provisions regarding defamation were abolished as of 1 October 2015 and are now met only with civil sanctions ('skadeserstatningslovens article 3-6a'). 


\subsection{Journalists'Reporting Privilege}

Since the Jersild judgment, it has been evident that punishing a journalist for assisting in the dissemination of statements made by another person in an interview would seriously hamper the contribution of the press to discussions of matters of public interest. Punishment should not be considered unless there are particularly aggravating reasons for doing so. ${ }^{19}$ This is so because news reporting based on interviews, whether edited or not, constitutes one of the most important means whereby the press is able to play its vital role of public watchdog.

However, impunity in this situation is not absolute and the right to freedom of expression can be surpassed if, for instance, the interviewee makes racist statements and it can be assumed that the motive of the journalist was to publish the racist statements in order to promote them..$^{20}$ The same goes for defamatory statements. Analytically, these cases can be seen as being the indirect statements of the journalist her- or himself.

As seen from the Jersild judgment, ${ }^{21}$ a journalist is only discharged from liability if the topic of the interview is of some public interest and its publication is not motivated by an illegal objective. It is not possible to list all the topics that are of some public interest in an abstract and relevant way, ${ }^{22}$ but it is important to emphasise, as a main rule, that the more gross the statement, the harder it is to establish that the topic is of any public interest. Whether the statement of an interviewee is relevant measured in relation to the topic, must also be part of the assessment. Likewise, it must be taken into account whether the statement was necessary to illuminate the topic. However, the final assessment must be based on the specific circumstances of the case in hand. When making such an assessment, the point of departure is the main rule of reporting privilege.

\subsection{Self-staged Stories and Committing Crimes}

In Denmark, and presumably in most other countries, in their eagerness to author an article or broadcast a television or radio programme, some journalists self-stage stories in the sense that they devise problems or concerns that would not have existed had the journalist not invented them. These journalists do not report news, they create news. Such conduct can be criticised from a journalistic and credibility point of view. From a

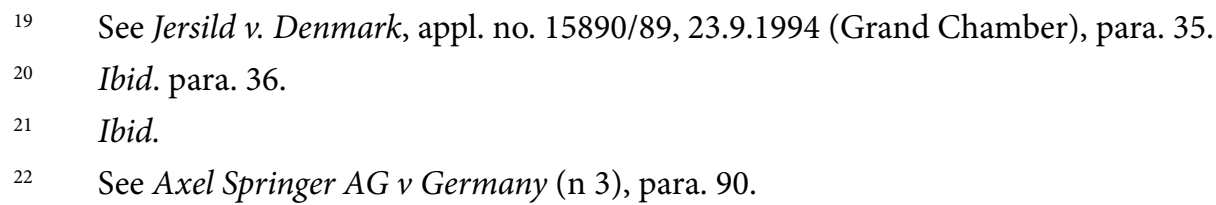


criminal legal perspective the focus must, however, be on whether the conduct leading to the invented story is lawful or not. If the conduct is lawful, all criminal law considerations are unnecessary. However, if the conduct is unlawful, the criminal legal considerations are complex. Some examples will demonstrate the issues in this regard.

In 2004, after the tightening of security systems at airports in consequence of the terror attack on i.a. the World Trade Center Complex in New York City in 2001, a journalist, together with a photographer, went into a steak restaurant in the transit hall of Copenhagen Airport to collect a so-called steak knife. With the knife hidden in a newspaper, he went out to a departure gate. At the gate the photographer took his picture while he waved the knife in the air. They were seen and afterwards stopped by the security guards at the airport. The next day, the journalist had an article and his picture published in a newspaper. The incident gave rise to some further tightening of the access to cutlery in the airport's restaurants.

The journalist was charged with illegal possession of a knife in a public place. The case went all the way to the Supreme Court where he was found guilty. However, the Supreme Court found that he should not be given any penalty, since the applicable law at the time of commission was somewhat vague and because of the journalist's motive combined with the short period of time he was in possession of the knife.

The conviction in itself was based on the reasoning that the journalist had selfstaged the story, and that the unlawful act had not been necessary to reveal the lapse in security. This was true in the opinion of the Supreme Court, even though a lawful research technique would have attracted less attention to the newspaper article. ${ }^{23}$

If one is to analyse the case from the standpoint of Article 10, it must first be noted that the facts of the case fell within the ambit of the Article, since the unlawful act was journalistic research conduct. There was thus some kind of assumption that the journalist's conduct was covered by freedom of expression. However, this is just the preliminary part of the analysis, since the applicable criminal law provision does not by its nature constitute a limitation of freedom of expression. Thus, journalists as well as anyone else cannot, in principle, be released from their duty to obey the ordinary criminal law on the basis that Article 10 affords them protection. Some special element is required to reverse that. The Mikkelsen and Christensen case, which is very similar to the steak knife case, further demonstrates the legal position. in the same airport hidden in his underpants. Afterwards he went to a toilet, took out the knife and went to a departure gate where his picture was taken. Because this act was committed before his eventual conviction by the Supreme Court in the first case, he was found guilty but again not imposed any sanction. See the High Court's judgment of 14 June 2010. 
Two journalists, ${ }^{24}$ preparing a documentary for a national television station about the import and distribution of illegal fireworks in Denmark - a very hot issue at the time - purchased illegal fireworks (eight chrysanthemum shells containing approximately two kilos of explosives). The journalists were not trained in the handling of fireworks. Consequently, as they brought them in their car to a police station in central Copenhagen, they were putting local residents and passers-by in potential danger. The journalists were found guilty by the High Court of having acquired illegal fireworks without permission from the municipal authority, contrary to Section 7 of the Fireworks Act. Each was fined DKK 6.000 (approximately EUR 800). The journalists explained that their motive was to show how easy it was to buy illegal fireworks and to gather information about the suppliers. They had filmed the purchase with a hidden camera.

In its judgment, the High Court acknowledged that the topic investigated by the journalists was of essential importance to society, and that the broadcast on television was deemed to have significant news and information value. However, the rules on the purchase of fireworks are based on compelling safety considerations and the journalists had not complied with these rules. The High Court ended this part of its judgment by stating that the journalists had independently planned and carried out a criminal act, that compelling reasons were required for obtaining impunity for the act and that there had not been such compelling reasons in this case.

The journalists applied to the European Court of Human Rights, where they claimed that the criminal conviction violated their right to freedom of expression as provided in Article 10 of the Convention. By its decision of 24 May 2011, the Court found that the application should be rejected as manifestly ill-founded in accordance with Article 35 and declared it inadmissible. The Court's reasoning is remarkable.

First, the Court established that, even though the criminal act involved journalistic research that did not in itself relate to freedom of expression, the facts of the case nevertheless fell within the ambit of Article 10. This had been uncertain until this decision. Next, the Court reiterated the phrase about journalists' duty to obey the ordinary criminal law. The Court assigned great weight to the fact that the journalists were not convicted for having produced a television programme or for having raised criticism against the authorities; they had only been found guilty of having intentionally acquired the chrysanthemum shells in breach of the Fireworks Act. The Court observed that the journalists' documentary programme had not been stopped or impeded in any way.

The Court also found it significant that it was not true, as claimed by the journalists, that the criminal act was necessary to demonstrate the points made in the TV programme. Furthermore, the Court assigned great importance to the fact that the national court had thoroughly examined the case and given relevant and sufficient reasons for the 
necessity of sanctioning the journalists, and had done so in application of Article 10 of the Convention. Finally, the Court stated that the penalty imposed could not be considered excessive.

Notwithstanding the journalists' duty to obey the ordinary criminal law, it is not insignificant that journalistic research conduct used in a journalistic documentary falls within the ambit of Article 10, even though the criminal law provision in question does not by its nature constitute a limitation of freedom of expression. This is so because research conduct is by nature the foundation of journalism and the basis upon which all journalistic outcomes are achieved, and thereby a derivative of the public watchdog functions. To this must be added that, only when the facts of a case fall within the ambit of Article 10, must the case be examined in accordance with that Article - also as regards the (severity of the) punishment. Such an examination is in itself a guarantee of a free press.

As seen from the Mikkelsen and Christensen decision, it is essential that, in their keenness to uphold the criminal law, national authorities do not punish the press for highlighting the critical state of affairs present in society. It is also essential that the national authorities distinguish between the criminal act and the journalistic outcome and, in that connection, refrain from stopping or in any way impeding the disclosure of the journalistic article or broadcast. It is the criminal act that may be subject to a criminal conviction, not the journalistic outcome as such.

In Denmark, and presumably in many other European countries, there have been several cases where journalists have self-staged stories and committed crimes in doing so. These cases have for example included the unlawful purchase of different kinds of weapons, ammunition, pepper spray, narcotics and other unlawful items, in order to show how easy it is to get possession of them. They have also involved the unlawful destruction of animals in front of the camera in order to provoke discussion of the methods used, the use of false identity papers to get a driving licence or other official document in the name of another person to show how easy it is to do. ${ }^{25}$

The examples are ad libitum and are only limited by the imagination of journalists. Because of this journalistic trend, it is very important that the national courts and the European Court of Human Rights keep a fairly firm hand in these cases. On the one hand, they must have a predominant main rule regarding the duties and responsibilities of journalists, thereby regarding the journalists' duty to obey the ordinary criminal law in cases where the applicable criminal law provision does not by its nature constitute a

25 See e.g. the District Court's judgment (Københavns Byret) of 19 November 1997, the High Court's judgment, U 2009.920 Ø, the District Court's judgment (Københavns Byret) of 12 November 2001, the High Court's judgment, U $2001.723 \varnothing$ and the District Court's judgment (Odense Byret) of 22 December 2010. As regards Norwegian case law see e.g. Rt. 1998 p. 34 and Rt. 2001 p. 1379. 
limitation of freedom of expression. On the other hand, given the underlying principles of freedom of expression, it is crucial that the courts leave room for impunity in cases where the topic is of essential importance to society in the proper sense of the word, and where the unlawful research conduct is actually necessary for the purpose of the journalistic product and the journalistic exposure is of great significance to society. These reasons must not be regarded cumulative since each of them is of significance per se if the research conduct shall be deemed to be within the law.

As regard the first requirement, it is important to bear in mind that a lot of issues are of significance to society. This is, however, not sufficient. In these cases the topic must be of essential importance to society to be able to overrule the ordinary criminal law.

Particularly the requirement that the (otherwise) unlawful research conduct is actually necessary for the purpose of the journalistic product must be scrutinised carefully - it is not enough to take the journalist's word for it. This is because a gentle or lenient application of this prerequisite is likely to open the floodgates to unlawful acts perpetrated by journalists and thereby to deceive the rule of law. In that connection it is paramount to underline that the assessment is a legal assessment, not a journalistic. ${ }^{26}$

Last but not least, the journalistic exposure must be of great significance to society. In other words, there must be a real need to have the topic put on the public agenda in the interest of society.

\subsection{Self-staged Stories by Making Other People Commit Crimes}

As a kind of subset of the aforementioned group of cases, there have been cases where a journalist creates news by inducing other people to commit acts of a remarkable kind so that the journalist can then report on them. In some of the cases the act amounts to a crime.

Obviously, the person who commits the crime is criminally liable, but the question is whether the same applies to the journalist as the accomplice who instigated the crime. When assessing this question, it is paramount to bear in mind that, in her or his quest for a story, the journalist has induced or sometimes manipulated an otherwise innocent person to commit a crime.

In one case, for example, a journalist made a radio listener stop by the nearest bakery and go in, buy a cake and then smash it into the face of the baker's assistant just to see how she reacted and broadcasted the incident live on the radio. ${ }^{27}$ In other cases, the purposes as such have concerned more serious issues related to relevant problems in

26 See along the same line $\varnothing y$, Medierett for journalister (Media law for journalists) (Cappelen Damm A/S 2013), pp. 240 f.

27 See the High Court's judgment, U 2006.2172 Ø. 
the society, but the method used has still been reprehensible. For example, in Denmark sexism against women has been a great problem. To throw light on that topic some journalists announced for young men to sexually assault strange women in the street while taping it with hidden camera to illustrate everyday sexism and how women react to it. ${ }^{28}$ In such cases, it follows from the fact that a third party's physical integrity was violated that not only was the immediate perpetrator criminally liable but also the journalists. The premise for this application of the law is the journalist's poor judgement and lack of appreciation of the seriousness of the crime.

In other cases, where no individual is harmed, the assessment is a bit more complex, but it will still point in the same direction if the act is criminalised in the interest of social order in a wide sense of the term. For instance, this will be the case if a journalist induces young people to commit falsification of documents in order to prove that the security level regarding proof of age is too low, due to the fact that it is very important in a civilised society that official documents should be reliable. ${ }^{29}$ Moreover, the same journalistic documentation could have been obtained by lawful means. Journalists must also be criminally liable in cases where they induce people to vote in a referendum or election in the name of another person just to prove that it is possible. ${ }^{30}$ Electoral fraud is very serious and can as a consequence have the effect that the referendum or election must be rerun, with serious economic costs for society and the risk that a great deal of the voters do not bother to vote again. That would harm democracy and would damage the citizens' trust in it.

It appears from cases like these that some journalists do not recognise the seriousness of their acts and how they can harm society and democracy. Even though the issues of most of the journalistic products were of essential importance to society and thereby had significant news - and information value, this fact does not grant journalists a carte blanche to commit any kind of crime or to induce others to commit them. The predominant main rule regarding the duties and responsibilities of journalists, including the journalists' duty to obey the ordinary criminal law in cases where the applicable criminal law provision, does not by its nature constitute a limitation of freedom of expression, must not be neglected. Exceptions can only be made under extraordinary circumstances, as accounted for above.

28 See MX.dk 4. May 2015, p. 6.

29 See the High Court's judgment of 20 March 2013.

30 See the District Court's judgment (Rønne Byret) of 30 September 2005. 


\subsection{Crimes Committed in Connection with Data Collection}

The case may be considered otherwise if a third party has committed a crime, but that crime was not instigated by a journalist. In this case, the journalist did not create news, but reported on news.

This was, for instance, the case in Denmark where a third party of his own volition breached his duty of confidentiality and showed some confidential material to a journalist. ${ }^{31}$ The third party was found guilty as the immediate perpetrator, ${ }^{32}$ but the journalist was acquitted. The acquittal was well-founded, even though the journalist in his newspaper articles disclosed classified information which breached national security (which is a separate crime in Denmark). This was because the topic was of essential importance to society, was highly discussed at the time, widely reported in the media, and because the journalist received the information without any kind of request. In addition, the harm done was of little account.

This acquittal also fell in line with the Dammann judgment. ${ }^{33}$ In this case, Switzerland was found to have violated a journalist's freedom of expression. The journalist had been convicted by the national courts and sentenced to a low criminal fine of CHF 500 (approximately EUR 325) for inciting another person to disclose an official secret. The facts of the case were as follows: the journalist investigated a spectacular robbery. In this regard he telephoned the public prosecutor's office and spoke to an assistant. She helped him find out whether the persons arrested in connection with the robbery had any previous convictions. This was a violation of her duty of confidentiality since the information was an official secret. ${ }^{34}$ The journalist did not use the information, but the episode was discovered by accident. The case thus concerned the journalist's common research- and investigative activities in connection with ordinary journalistic data collection about events that had already happened. The case did not concern restraint of publication as such, or a criminal conviction following a publication.

The Court assigned weight to the following circumstances: the confidential information could have been obtained by other means, such as consulting case law reports or press archives; in the circumstances the national authorities' justification of the conviction was not really relevant or sufficient; and the information had been of a kind that raised matters of public interest, given that the spectacular robbery had been widely reported in the media. The journalist had not tricked, threatened or pressured the assistant into disclosing the desired information, so the national authorities had to bear a large

31 See the District Court's judgment (Københavns Byret) of 4 December 2006.

32 He did not ask for and was not granted by the journalist any kind of source protection.

33 See Dammann v. Switzerland, appl. no. 77551/01, 25.4.2006.

34 The assistant was convicted and lost her employment in the Public Prosecutor's office, but this case was not brought before the European Court of Human Rights. 
share of responsibility for the indiscretion committed by the assistant. Since the journalist had not made the information public, no harm had been done to the rights of the persons concerned.

Finally, the Court attached great weight to the conviction itself, since it amounted to a kind of censure that would be likely to discourage journalists from carrying out research with a view to prepare an informed article on a topic of current affairs. Punishing a research activity like that would be likely to deter journalists from contributing to public discussions of issues affecting the life of the community, and was thus liable to hamper the press in its role as both a provider of information and a public watchdog.

The Court's reasoning is of significance and emphasises that the national courts must make an individual in-depth assessment in every case involving journalists and not just run on 'judicial autopilot' in these cases. Every relevant detail and aspect of the case must be carefully considered, and a proposed sentencing must be weighed against the consequences for the free press and the tasks of the press to provide information and serve as the public watchdog.

This is not to say that, when reporting on current affairs and news, journalists are given a free rein to do as they like. The main rule is that, in their eagerness to report the news, journalists must not violate the rights of others. The notion of the free press does not in itself discharge journalists from obeying the ordinary criminal law.

One kind of potential crime in connection with data collection is the use of a hidden camera. In Denmark this is not in itself criminalised. Journalists as well as other people are free to make use of a hidden camera in places that are open to the public. ${ }^{35}$ If a recording is made without consent or other justifications in a place that is not open to the public, ${ }^{36}$ this will be punishable under Section 264 (a) of the Danish Penal Code. However, if the recording is made as part of research, criminal liability will depend on an assessment made in accordance with Article 10 of the Convention. The starting point for such assessment is that, even when reporting on matters of public interest, journalists must respect the law and must not infringe other people's right to personal integrity.

In the Haldimann case, ${ }^{37}$ the Court was for the first time called upon to examine an application concerning some journalists' use of a hidden camera to obtain information on a subject of public interest. The journalists were convicted for having recorded and broadcasted an interview with a private insurance broker using a hidden camera. The broadcast was part of a television documentary intended to denounce the misleading ad-

35 This does not mean that any publication of the recording is permitted. This assessment depends on whether a recording contains information of a private nature which should be concealed from the public. The publication is also regulated by the ethics of journalism.

36 As is common practice with e.g. wedding parties where everybody takes pictures and photography has not been prohibited in advance.

37 See Haldimann and Others $v$ Switzerland (n 13). 
vice provided by insurance brokers and thereby the inadequate protection of consumers' rights, which was a hot topic in Switzerland at the time. The person filmed was not targeted in a personal capacity but as a representative of a particular professional category. The broker's face and voice were disguised in the broadcast. The journalists were fined because it was found that they could have used a different approach causing less harm to the broker's private interests.

First, the Court observed that the subject of the broadcast was part of a public debate of general interest. ${ }^{38}$ Furthermore, the Court observed that the documentary had not focused on the broker, but on specific commercial practices used within a particular professional category. The recording had not been made on the broker's private premises or on the insurance company's domicile. ${ }^{39}$ The journalists had acted in accordance with the ethics of journalism as defined by Swiss law and had thereby acted in good faith and on accurate factual basis. They had provided reliable and precise information. ${ }^{40}$ While the documentary reflected negatively on the broker, his face and voice had been disguised so that the interference with his private life had not been serious enough to override the public's interest in receiving information on the alleged malpractice in the field of insurance brokerage. ${ }^{41}$ It could not be considered a mitigating circumstance that the penalty imposed was lenient, because the conviction was liable to discourage the media from expressing criticism, even though the applicants had not been prevented from broadcasting their documentary. ${ }^{42}$

It can be inferred from the Court's judgment that: if the matter bears a significant impact on a debate on a subject of general interest; if the recording takes place in a non-private area not belonging to the interviewee or her or his company; if the broadcast is focused on the professional conduct of a representative of a commercial company (not on her or him as a private person) and if in the broadcast due consideration is given to the interviewee's privacy, the conviction of a journalist for using a hidden camera in her or his journalistic data collection and the broadcast of the recorded interview, infringes the public's right to information - even if the penalty imposed is lenient. On the other hand, the Court's judgment says nothing about what its finding would have been if the recording had been made on the premises of the interviewee or if the broadcast had not paid due consideration to her or his private life.

As regards the latter, the Bremner $v$. Turkey judgment is of great significance. ${ }^{43}$ In this case the Court was again called upon to examine a case concerning the use of a

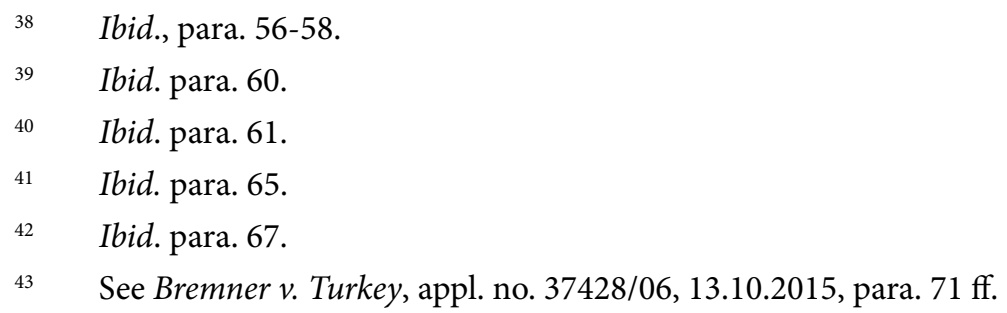


hidden camera and the broadcast of the recorded. On this occasion the applicant was the journalistic target and the Court held that there had been a violation of Article 8 (the right to respect for private life).

The applicant was, besides his ordinary job, a sort of a Christian missionary. $\mathrm{He}$ had held a meeting with some people whom the applicant believed wished to learn more about Christianity. The meeting was filmed using a hidden camera. In the end of the meeting a journalist entered the room with a camera and a microphone asking the applicant for an interview about his activities. The recorded was broadcasted in a television documentary which, according to its presenter, concerned covert activities conducted in Turkey by 'foreign pedlars of religion'. The applicant's image was showed and it was neither blurred nor disguised. The applicant sued the presenter and producers of the programme, claiming damages, but his claim was dismissed by the Turkish courts.

As in the Haldimann case, the Court observed that the subject of the broadcast - religious proselytising - was undeniably a matter of general interest. ${ }^{44}$ The programme had been critical, using offensive terms such as 'pedlar of religion' which amounted to a value judgment. As regards the method used, the Court ascertained that a technique as intrusive and as damaging to private life as a hidden camera must in principle be used restrictively. The Court underlined that the use of hidden cameras might prove necessary for journalists when information was difficult to obtain by any other means. However that tool had to be used in compliance with ethical principles and with restraint. ${ }^{45}$ As to the fair balance between the competing interests - the right to freedom of expression on the one hand and the right to respect for privacy on the other - the Court observed that the applicant had not placed himself in the public arena. He had published an advertisement for the meeting, but this could not have led him to suspect that he might be the subject of public criticism. He thought that he was merely meeting a group of individuals interested in Christianity, and he had not during the meeting committed any illegal act.

Even though the topic of the broadcast was of general interest, the Court did not find any general-interest justification for the journalists' decision to broadcast his image without blurring it. The applicant was not famous. Neither was the broadcasting of his image newsworthy and did not contribute to the topic in any useful way. ${ }^{46}$

It can be inferred from the Court's judgment that the broadcast must give due consideration to the individual's privacy and that a fair balance must be struck between the competing interests, even if the subject is of an 'undeniably' public interest.

In this connection it must be emphasised that the standard or yardstick is not whether the broadcast amounted to 'good television'. Rather it is whether the broadcast

\footnotetext{
$44 \quad$ Ibid. para. 72.

$45 \quad$ Ibid. para. 76.

$46 \quad$ Ibid. para. $82 \mathrm{f}$.
} 
per se contributed to the topic in a serious way and, on the whole, whether the shooting and broadcast exercised due caution. This includes the place of the recording (public or private place), the focus of the broadcast (professional conduct or the recorded person's more or less private qualities), if the recorded person had placed him- or herself in the public arena, if the person had committed any illegal act and if the journalists had acted in accordance with the ethics of journalism and thereby acted in good faith and on accurate factual basis and have provided reliable and precise information.

Even with these criteria, the balancing is not easy to strike. This is due to the fact that freedom of expression and the role of the press as public watchdog - and thereby as the mouthpiece of the people and the entity, with the role of bringing up social problems for discussion and guaranteeing a healthy operation of democracy - are of great importance to society. In many cases the press is not able to fulfil its task without bringing somebody in the soup, even with a hidden camera. This comes as an unavoidable price. On the other hand, not every topic is of genuine public interest and in many cases the broadcast of the recorded does not provide anything substantial to the illuminating of the topic, but is motivated by a desire to pin something on somebody to make 'good television'. In these cases it is very important that the national courts - and in the end the European Court of Human Rights - uphold the principle of right to privacy. The latter principle is also protected by the Convention, which is of equal value and consequently deserves equal respect. ${ }^{47}$

In some journalists cases the Court has stated that it

is not for this Court, nor for the national courts for that matter, to substitute their own views for those of the press as to what technique of reporting should be adopted by journalists. In this context the Court recalls that Article 10 (art. 10) protects not only the substance of the ideas and information expressed, but also the form in which they are conveyed. ${ }^{48}$

This statement has raised expectations among journalists and has been hopefully alleged in the pleadings of defence lawyers. ${ }^{49}$

When assessing this statement it is, however, important to take the standpoint that prior restraints, even on the press, are not in themselves incompatible with Article 10. The Court's statement about 'technique of reporting' must be read in that light and the statement must therefore be seen as a 'warning' to the national governments and courts not to impose in advance a too far-reaching kind of censorship to illegalise common journalistic practice. ${ }^{50}$ However, this is not the same as to say that journalists by needless

47 See further below.

$48 \quad$ See e.g. Jersild v. Denmark (n 19), para. 31. See also Kjølbro (n 7) p. 760.

49 See e.g. U 2008.671 H (n 23).

50 See also Harris, O’Boyle \& Warbrick (n 10) pp. 639 f. 
intrusion of privacy cannot be held liable if they overstep the necessary boundaries in the case at hand. In hidden camera cases, the striking of the right balance is of exceptional importance since the technique used is by nature intrusive and the broadcasting of the recorded can easily cause harm to the interviewee's private interests.

Another possible crime connected with data collection is making unlawful searches of a data register at variance with the aim of the register. This will normally be in violation of the Data Protection Act and thereby a violation of the integrity of the person whom the data concerns. Sometimes illegal hacking is involved. ${ }^{51}$ The overriding main rule in these cases must therefore be that journalists are as liable as anybody else. This is actually important, since an individual's personal data is gathered in all kinds of data registers in respect of every part of the individual's private life. Freedom of expression does not grant journalists the right to misuse these data registers since this could have immeasurable consequences for the recorded person and thereby for the way modern society is organised.

The same applies if, for example, in order to get a visiting permit and obtain an interview with a prisoner, a journalist submits a false statement of her or his relationship with the prisoner or her or his business. ${ }^{52}$ This is due to the fact that the misuse of security systems in the name of freedom of expression may result in the security system being tightened up, with an irreparable damage to the prisoners and to society as such. In the old days, prisoners were as a main rule not allowed visitors. This was detrimental to their psychological health and worked against their rehabilitation. Because of that, the rules were amended and today it is possible for most prisoners to have visitors 'under certain conditions', precisely because consideration for the prisoner is not the only matter to be taken into account. Often there may also be powerful opposite considerations. If journalists were granted impunity in these cases on the grounds of freedom of expression, this could not fail to have negative consequences.

In Denmark there have been several cases of journalists' trespassing on private property in order to report on, for instance, demonstrations that took place on the property. To start with, the journalists were convicted, but just after Denmark lost the Jersild case, the Danish Supreme Court became more sensitive to the Convention and its (special) status in cases concerning journalists. Since then, a large number of trespassing

51 This was the case in the British News of the World case and the Danish Se \& Hør case (still pending).

52 This was the case in Denmark. The journalist was fined for his false statement, but his newspaper article was not stopped or impeded in any way. See the District Court's judgment (Assens Byret) of 18 August 2005. 
journalists has been acquitted. ${ }^{53}$ If a case on trespassing by journalists were to be referred to the Court for instance by the property owner, ${ }^{54}$ it must be expected that the Court will assign great weight to the topic of the demonstration and consider whether it is of significance to the public that the journalists report on it and do that from the 'inside'.

It must also be expected that the Court will attach significant weight to whether there have been a serious violation of the owner's right to privacy. In that connection, the Court will hopefully attach substantial weight to whether the demonstrators and the journalists were joined together in some kind of conspiracy, with the effect that the demonstration would not have taken place if the journalists had not been present, or the demonstration became (more) violent and ran out of control because of the journalists' presence.

Hopefully, the Court will also assign weight to information concerning the journalists' behaviour in general and to information about possible (other) crimes committed by the journalists at the scene. It is not easy to strike a balance because the press has the task to report on incidents in society and the public has a right to receive this information. However, this very important task is not the only important value in the democratic society. Other people's right to privacy is also of importance and must be attributed weight. As stated by the Court, these two rights (to freedom of expression and to privacy) are of equal value and deserve equal respect..$^{55}$

In Pentikäinen v. Finland the applicant, a media photographer, was apprehended during a demonstration that turned into a riot. Subsequently, he was convicted for disobeying a police order to disperse. He was not imposed any sanctions. The Court did not find a violation of Article 10.

The Court assigned weight to the fact that the police had not deliberately prevented or hindered the media from covering the demonstration. The applicant had not been prevented from carrying out his work as a journalist either during or after the demonstra-

53 The first case concerned a demonstration against a large bridge construction which the demonstrators opposed. The demonstration involved malicious damage to property in the then Minister for the Enviroment's private garden. A journalist and a photographer followed the demonstration into the garden and stayed there as long as the demonstrators were there. See U $1994.988 \mathrm{H}$. This judgment was followed up by other judgments e.g. U $1999.1675 \mathrm{H}$, the District Court's judgment (Københavns Byret) of 3 December 1997, the High Court's judgment (Østre Landsret) of 28 August 2008 and the District Court's judgment (Frederiksberg Byret) of 16 December 2008.

54 See also Article 1 in Protocol 1 to the European Convention for the Protection of Human Rights and Fundamental Freedoms (20 March 1952).

55 See among others Axel Springer AG v Germany (n 3), para. 87. See also Moosavian, Deconstructing 'Public Interest' in the Article 8 vs Article 10 Balancing Exercise, 6(2) Journal of Media Law (2014) pp. 40 ff. and Jacobs, White \& Ovey, (n 6) pp. 449 ff. 
tion, and his equipment had not been confiscated - he was only convicted for disobeying the police. ${ }^{56}$

The Court noted that the case fell within the ambit of Article 10 because 'his exercise of his journalistic functions had been adversely affected as he was present at the scene as a newspaper photographer in order to report on the events. ${ }^{57}$

At the same time the Court emphasised that even though journalists may face a conflict between their general duty to abide by ordinary criminal law and their professional duty to obtain and disseminate information, thus enabling the media to play its essential role as public watchdog,

it has to be emphasised that the concept of responsible journalism requires that whenever a journalist - as well as his or her employer - has to make a choice between the two duties and if he or she makes this choice to the detriment of the duty to abide by ordinary criminal law, such journalist has to be aware that he or she assumes the risk of being subject to legal sanctions, including those of a criminal character, by not obeying the lawful orders of, inter alia, the police. ${ }^{58}$

This is a rather incisive remark that leaves the risk of a conviction solely on the journalist's shoulders. This must also be the outcome in the above-mentioned trespassing cases especially if the trespassing has induced a serious violation of the owner's right to privacy.

\subsection{Journalists' Own Defamatory Statements}

From time to time journalists are involved in cases of defamation. In the following I will briefly outline the state of the law in this field.

Firstly, it is important to make a main distinction between cases where the journalist expresses her- or himself in a private dispute, even if this is done in public, and cases where the journalist is acting as a journalist. If the journalist makes defamatory remarks in a private role, she or he must be treated in the same way as anybody else, since the special status that journalists enjoy in a democratic society related to freedom of expression does not, as mentioned above, relate to their own capacity, so to speak, but to their function as the public watchdog. In the Janowski case, in which Janowski was found guilty of making insulting remarks about some municipal guards, the Court stated that the insulting remarks did not 'involve the issue of freedom of the press since the applicant, although a journalist by profession, clearly acted as a private individual on this occasion. ${ }^{59}$

56 See Pentikäinen v. Finland, appl. no. 11882/10, 20.10.2015 (Grand Chamber), para 89.

$57 \quad$ Ibid. para 83.

$58 \quad$ Ibid. para 110.

59 See Janowski v Poland, appl. no. 25716/94, 21.1.1999 (Grand Chamber), para. 32. 
Secondly, it is important to make a distinction between cases where the journalist merely reports statements made by another person in an interview or reports from a debate or a conference, and cases where the journalist disseminates her or his own remarks. As discussed above, journalists have a reporting privilege, and to punish a journalist for her or his reporting would seriously hamper the contribution of the press to discussions of matters of public interest. In this context, punishment should not be contemplated unless there are particularly strong reasons for doing so.

This leaves us with defamatory cases where the journalist comments (as a journalist) on a matter following exhaustive research. In such cases a fair balance must be struck between the journalist's right to freedom of expression and the third party's right to protection of her or his reputation as covered by Article 8 of the Convention. It is to be noted that in order for Article 8 to come into play an attack on a person's reputation must attain a certain level of seriousness and in a manner causing prejudice to personal enjoyment of the right to respect privacy. Article 8 cannot be relied on in order to complain about a loss of reputation which is the foreseeable consequence of one's own actions. ${ }^{60}$

On several occasions, the Court has emphasised that the outcome of a case should not, in principle, vary according to whether it has been lodged by the journalist under Article 10 or under Article 8 by the person who is the subject of the article or broadcast. This is because, as stated above, both of these rights deserve equal respect. ${ }^{61}$

In these, as well as in other defamatory cases, the Court requires the domestic courts to distinguish between statements of fact (factual allegations) and value judgments. ${ }^{62}$ This is due to an assessment in accordance with the requirement in Article 10 (2) of 'necessary in a democratic society'. While the existence of facts can be demonstrated, the truth of value judgments is not susceptible of proof. ${ }^{63}$

If the topic is of public interest and the statement constitutes a statement of fact, an interference with the journalist's freedom of expression is not necessary in a democratic society if the allegation is proven true, or if the journalist has acted in good faith on an accurate factual basis and has provided reliable and precise information in accordance with the ethics of journalism. ${ }^{64}$ The Court has enumerated five additional criteria ${ }^{65}$ that are relevant for balancing the right to freedom of expression and the right to respect for private life: (1) how well-known the person concerned is and what is the subject of the

60 Such as the commission of a criminal offence. See Axel Springer AG v Germany (n 3), para. 83.

$61 \quad$ See Axel Springer AG $v$ Germany (n 3), para. 87.

62 See also Harris, O’Boyle \& Warbrick (n 10) pp. $697 \mathrm{ff}$.

63 See for instance OOOVesti and Ukhou v Russia, appl.no. 21724/03, 30.5.2013, para. 64.

64 See for instance Pedersen and Baadsgaard $v$ Denmark, appl. no. 49017/99, 17.12.2004, para. 71 ff., Björk Eidsdottir v Iceland, appl. no. 46443/09, 10.7.2012, para. 66 ff. and Prompt v. France (n 8), para 47.

65 Besides the criterion of the public interest. See also Harris, O’Boyle \& Warbrick (n 10) pp. $692 \mathrm{ff}$. 
report; (2) the prior conduct of the person concerned; (3) the method used to obtain the information and its veracity; (4) the content, form and consequences of the publication; and (5) the severity of the sanction imposed. ${ }^{66}$

If the topic is of public interest, but the statement instead constitutes a value judgment, interference in the journalist's freedom of expression will not be necessary in a democratic society if there is a sufficient factual basis to support the statement, and the statement is reasonable under the circumstances. ${ }^{67}$ These criteria are rather vague, but according to the Court's case law the following three indicators can be of guidance: how coarse the statement is, the circumstances in which the statement was put forward, and the relevance of the statement in correlation with the topic. The interference objected to must be looked at in the light of the case as a whole.

In Niskasaari and Otavamedia Oy v Finland the journalist (Niskasaari) had been found guilty of defaming another journalist and was fined EUR 240, with EUR 2000 payable in damages. The applicant had published articles in which he criticised the manner in which two TV documentaries had been made. In particular the applicant alleged that some figures used in the documentaries had been fabricated and that the evidence of one researcher had been included in one of the documentaries even though one of the reporters knew it to be false.

The Court determined that the topic of the articles - the limits of critical and investigative journalism - was clearly a matter of legitimate public interest. Both parties were professional journalists who were relatively well-known to the general public. The complainant had been given the opportunity to reply - which he did - and no details of the articles were obtained by subterfuge or other illicit means. The Court also attached importance to the fact that the complainant was an investigative journalist involved in making TV documentaries on controversial issues for a public broadcasting company. Consequently, he was engaged in an activity very much in the public domain, in a manner and in circumstances where he could himself expect to be the subject of robust scrutiny, comment and criticism regarding his professional conduct. In addition, the Court noted the severity of the sanctions imposed on the applicant. All this, together with the fact that the national courts had not conducted a proper examination of the case in accordance with Article 10 of the Convention and the Court's case law, made the Court consider that there had been a violation of Article $10 .^{68}$

This case is interesting, not just because it shows a dispute between two journalists and thereby that journalists from time to time also must get a taste of her or his own

\footnotetext{
66 See Axel Springer AG v Germany (n 3), para. 89 ff. and Niskasaari and Otavamedia OY v Finland (n 8), para. 49.

$67 \quad$ See Tusalp v Turkey, appl. no. 32131/08, 21.2.2012, para. 43.

68 See Niskasaari and Otavamedia Oy v Finland (n 8), para. 50 ff.
} 
medicine, but also because it shows that striking a fair balance requires consideration of the case as a whole, including the behaviour of both parties. Finally, the case shows the importance of the national courts' examination of the case.

The national courts must apply standards which are in conformity with the principles embodied in Article 10 and the national courts must adduce reasons that are relevant and sufficient.

\section{Concluding Remarks}

Journalists and the press have a duty to impart information and ideas on all matters of public interest. Not only does the press have this task, the public has a right to receive such information and ideas. This gives journalists an essential role in a democratic society.

On the other hand, freedom of expression is not the only valuable human right. The right to privacy is also of significance. As mentioned above, these two rights; the right to freedom of expression and the right to privacy, are of equal value and deserve equal respect. It is not in the interest of society that freedom of expression at any price takes precedent over the right to privacy, sacrificing the latter. A fair balance must be struck between the competing interests. In striking that balance the courts must, among other criteria, weigh the importance for society of the subject of the article or the broadcast against the intrusive or harmful effect on the individual.

In the old days, the domestic criminal courts dealt with very few cases in which journalists stood on trial. Today, such cases form a separate category. Every year the Court delivers a number of judgments regarding journalists - especially compared with the number of journalists in Europe and the fact that journalists do not operate alone in the news market, since many young people get all their information from social media, that is information not necessarily provided by a journalist. The volume of judgments of the courts is not due to the fact that today more events worthy of reporting take place. It is evident, that part of the reason is that freedom of expression of journalists is attributed more significance today because of the recognition of the essential role of this freedom in a democratic society.

At the same time it also appears as if the significance of freedom of expression makes some journalists believe that they are sacrosanct and therefore above the law. It also makes some journalists believe that in the balancing between the competing interests (normally freedom of expression and the right to privacy) the fairness always is on the side of free speech. As shown, this cannot be accepted. Journalists are free to do all the things free people are free to do in a free society but, apart from the special privilege 
attached to reporting, journalists are, in principle, not released from their duty to obey the ordinary criminal law. Article 10 only affords them immunity in exceptional circumstances. This applies in particular if the concrete criminal law provision does not by its nature constitute a limitation of freedom of expression. Of course, the special status of journalists as public watchdogs is to be considered seriously in every single case, but the bedrock principles that lie behind freedom of expression dictate that journalists are not to be treated as a state within the state and immune to the rule of law. The job description of journalists must therefore take criminal law into account.

So the answer is 'No' Journalists are not to be punished for doing their job, provided that they do not overstep certain bounds, particularly the bounds set by the ethics of journalism and the ordinary criminal law as interpreted in conformity with Article 10 and the Court's case law. 